\title{
Development of Media Using Adobe Flash CS6 With a Learning by Doing Approach Sewing Technology in the Student Grade X Vocational High School of Fashion Design
}

\author{
Martha Linora br.Sitompul ${ }^{1, *}$ Harun Sitompul $^{2}$ Farihah $^{3}$ \\ ${ }^{1,2,3}$ Master of Education Technology Education, Medan State University \\ ${ }^{*}$ Corresponding author. Email: linoramarthasitompul1@ gmail.com
}

\begin{abstract}
This study aims to determine: (1) feasibility level of media product development using Adobe Flash CS6 in sewing technology training courses, (2) the effectiveness level of media product development using Adobe Flash CS6 with a learning by doing approach in sewing technology training courses. This study uses a research and development design with ten steps of implementation referring to the theory of Borg and Gall. The research method consists of: (1) subject matter expert validation, (2) instructional design expert validation, (3) media expert validation (4) individual trial, (5) small group trial, and (6) limited field trial; and calculate the value of learning outcomes for sewing technology subjects developed.

The test subjects consisted of four subject matter experts, two instructional design experts, two instructional media experts, three students for individual trials, nine students for small group testing and 30 students for limited field trials. The data about the quality of this development product were collected by using a questionnaire and analyzed by using quantitative descriptive analysis text. The results showed that media products by using Adobe Flash CS6 with a learning by doing approach which was developed in the sewing technology training eye for class X Fashion Design students at SMK N 1 Siantar qualified and suitable for use based on material expert validation including content feasibility with an average of 92.5 on very good criteria, presentation feasibility with an average of $92.0 \%$ on the very good criteria, the language aspect with an average of $90.0 \%$ on the very good criteria, and the graphic aspect with an average of $92.5 \%$ on the very good criteria. For the validation of learning media experts an average of $73.8 \%$ stated good and design expert validation with an average of $81.17 \%$ on very good criteria.

Use of learning media by using Adobe Flash CS6 with a learning by doing approach more effectively can improve student learning outcomes, this is indicated by the acquisition of student learning outcomes who are taught using learning media developed higher with an average of 83.10 of student learning outcomes who are taught using learning media fragments of clothing
\end{abstract}

Keywords: Learning Media, Sewing Technology.

\section{INTRODUCTION}

The task of a teacher is to help students develop their potential so that students become fully human, who can help themselves through the skills they have, for that teacher competence is needed to create fun learning by using various facilities and infrastructure and technology.

Along with the journey and progress of science and technology, it requires effort and hard work for the world of education to find appropriate technology to improve the learning process and facilitate students in learning. It is intended that the learning process of vocational students in particular is not just learning practice, but learning to understand the meaning of the future through learning activities that contain renewal to link theoretical and practical learning in a more real way.

State Vocational High School (SMK) 1 Siantar and SMKN 3 Pematang Siantar are vocational schools for 
technology and tourism groups. SMKN 1 Siantar with the address at Jalan Sangnawaluh Km.3,5 Siantar District, Simalungun Regency. SMKN 1 Siantar consists of 4 majors, namely Fashion, Skin and Hair Beauty, Multimedia and Computer Network Engineering. SMKN 3 which is located at Jalan Raya Medan P.Siantar Km 10.5, Siantar Martoba District, Tambun Nabolon Village Pematangsiantar City consists of these majors, namely Fashion Design, Skin and Hair Beauty, Hospitality Accommodation, Software Engineering, Catering and Computer Engineering Network.

SMK Negeri 1 Siantar and SMKN 3 P.Siantar, especially the fashion department, strive to make their graduates become creative, skilled, independent and innovative students and the success concept of a learning goal requires a needs assessment (need assessment). This is done to solve the problem, as well as find the right solution.

Based on preliminary observations made by interviews conducted by researchers with one of the productive teachers of fashion at SMKN 3 P. Siantar named Mrs. Martiani Samosir, SPd that in the implementation of sewing technology learning on students, the number of students who obtained good learning outcomes during learning took place only about $70 \%$ and data obtained from the teacher concerned that out of 88 students from the 2018 batch there were 14 students who were incompetent because they did not reach the KKM score (75) with details of 8 students getting a score of 70, who got a score of 65 as many as 2 students and 4 students with value 60 .

One of the fashion teachers at SMKN 1 Siantar, Mrs. Elvi Sinambela, SPd, stated that the learning outcomes of competent students were only about $50 \%$ and the data obtained from the 2018 school year teachers which consisted of 63 students, there were 18 students who were incompetent and had not reached the KKM score (75) with details of 10 students getting a score below 75, who got a score below 70 as many as 8 students.

The results of the needs assessment (needs assessment) using interviews that have been conducted and observations at SMKN 3 P.Siantar and SMKN 1 Siantar found many difficulties faced by teachers, this is due to: (1) Teachers teaching so far are still theoretical. monotonous. (2) Teachers are less capable in designing and making interesting media (3) Teachers do not use strategies in giving lessons (4) Teachers are reluctant to use available technological facilities, (5) Teachers have not been able to conducive class for optimal practical learning, (6 ) Limited facilities and infrastructure as well as costs, (7) Learning outcomes of technology subjects are categorized as still not competent so that further improvements are needed.

Class $\mathrm{X}$ sewing technology training subjects are materials that consist of materials and manufacture.
In other words, the teacher as a learning developer in addition to using media must also take a learning approach so that it can encourage students, and make it easier for students to follow the learning process and relate new information to relevant concepts contained in one's cognitive structure. as well as meaningful learning, the occurrence of interactions in learning The learning approach can be interpreted as a way to determine activities in the learning process that are general in nature, in which it accommodates inspiration to strengthen and underlie learning strategies with certain theoretical scopes (Taufik, 2010: 12). The use of information technology suddenly applies to all levels as a medium or a means of bridging in the implementation of distance learning and we must be ready to make changes because at this time we are entering a new concept with a change in perspective to build and explore student competencies. One of them is by using multimedia-based learning media. This is because multimedia uses a combination of text, graphics, audio and video animation that can be presented in one technology such as a computer or television (Bates \& Poole, 2003: 60).

Adobe Flash is one part of multimedia and Adobe Flash can overcome difficulties in learning because Adobe Flash has advantages such as making illustrations, making animations only require a small memory, the resulting program is interactive, and has interesting features and so on

In line with the results of Unaisah's research (2018) on media developed using the Adobe Flash application for basic design training courses at SMKN1 Sapotasari. Which aims:

1) Develop media with Adobe Flash Material Design Principles.

2) Measuring the feasibility of the media developed for the Design Principles material.

The research that developed the Thiagarajan model was carried out only in 3 stages, namely define, design, and develop. Data collection methods were carried out by interviewing, observing, making documentation, conducting literature studies and taking questionnaires, while for the validity of the instrument used content validity, the results were very feasible and instrument reliability using Cohen's Kappa. This data analysis uses descriptive quantitative.

In other words, currently it is more effective to use active or experiential teaching techniques, learning by doing or an approach that involves students and is directed and systematic so that by teaching students will produce experiences according to the needs of the work industry.

This learning media is needed as a solution to problems in learning to make rompok, serip and depun, 
namely media that are able to assist teachers in presenting material to students clearly, and can show the process like actual practice because the presentation of material can be more easily understood and mastered and students are required to learn while practicing directly the material being taught by watching the media being developed because in it there are packaged material and video tutorials and there are also practice questions to hone students' knowledge skills after studying the material. This aims to make it easier for class $\mathrm{X}$ students to understand the steps for finishing the edges of clothes

Based on the background of the problem, problem identification, and problem limitations that have been described, the problems in this research are formulated as follows: (1) Is the media using Adobe Flash CS6 with a learning by doing approach suitable for use in the Sewing Technology training course for class X SMKN? 1 Siantar? (2) Is the media using Adobe Flash CS6 with a learning by doing approach effective in the Sewing Technology training course for $\mathrm{X}$ grade students of SMK N 1 Siantar?

\section{METHOD}

This research is a development research using Adobe Flash CS6 application with a learning by doing approach. The samples of this study were 30 students of class $\mathrm{X}$ Fashion Design at SMK N 1 Siantar and 30 students of class X Fashion Design at SMK N 3 Siantar.

The development procedure that must be carried out to produce interactive multimedia in the material makes various kinds of clothing edge finishes for students of SMK Negeri 1 Siantar using the Borg \& Gall development model. The development procedure taken to produce medical products will be divided into five stages (Borg \& Gall: 1983), namely: (1) The first stage is conducting preliminary research, this stage includes literature study and field survey. (2) The design stage, at this stage begins with the preparation of sewing technology materials, designing competency standards and learning indicators, subjects, sub- subjects and learning objectives. (3) The product development stage, which begins with collecting materials, making flowchart views, making storyboards, enter the material a computer program (software) and document it on a CD. (4) The fourth stage is product review and trial in the context of product revision, at this stage the initial development is validated by media and materials experts, stage I revision, then small group trial, revision II, field trial, Revision III, reflection students, revision IV to produce the final product of the media in learning sewing technology that is in accordance with the needs and goals that have been set. (5) The last stage is the effectiveness test which aims to determine the effectiveness of the developed product. then small group trial, revision II, field trial, revision III, student reflection, revision IV to produce the final product of media in sewing technology learning that is in accordance with the needs and objectives that have been set. (5) The last stage is the effectiveness test which aims to determine the effectiveness of the developed product. then small group trial, revision II, field trial, revision III, student reflection, revision IV to produce the final product of media in sewing technology learning that is in accordance with the needs and objectives that have been set. (5) The last stage is the effectiveness test which aims to determine the effectiveness of the developed product.

Product trials in this development will be carried out by going through the following steps:

1) The first step is to determine the target of the trial, namely learning design experts, material experts, and media experts. Then it will be analyzed and concluded as a basis for making improvements to the product (revision II).

2) The second step is individual testing. Products and questionnaires will be given individually with the aim of finding out if the product is faulty after being checked and given advice by experts.

3) The third step is a small group trial in this step the product and questionnaire are given to small groups that are taken at random from students. The input from trial III is then used as the basis for making product improvements (Revision III).

4) The fourth step is a large group (field) trial. This trial was carried out to find out whether there were still deficiencies, so based on the input obtained, improvements would be made (revision IV). If not, then the product can be declared worthy as a viable learning resource in the field.

At this stage the instruments used are questionnaires and learning outcomes tests. Questionnaires were given to learning material experts, learning design experts, media experts.

\section{Study Results Test}

The learning outcomes test is used to see the effectiveness of the application of learning media by comparing the final test scores that are taught with the developed media with the final tests that are taught without using interactive media-based learning media. The form of the learning outcomes test used is a multiplechoice test consisting of 20 valid test items covering the cognitive areas $\mathrm{C} 1$ (remembering), $\mathrm{C} 2$ (understanding), C3 (application), C4 (analysis), C5 (evaluation), C6 (make). Each correct answer is given a score of 1 and the wrong answer is given a score of 0 (zero). The quality of the instrument is indicated by its validity (validity) and reliability (reliability). 
Hypothesis testing using one-party t- test (right side) is used to determine the effect of a treatment, namely the multimedia learning media product developed is able to improve learning outcomes in sewing technology training courses.

$$
\mathrm{T} \text { count }=\frac{\bar{X}_{1}-\bar{X}_{2}}{s \sqrt{\left(\frac{1}{n_{2}}\right)+\left(\frac{1}{n_{2}}\right)}}
$$

(Sudjana, 2005:239)

For feasibility analysis, namely the feasibility validation data from experts and students' positive responses to the developed learning multimedia. The data obtained is converted into quantitative data through a Likert scale of 1 to 5 with criteria Very good $=5$, good $=$ 4 , $\operatorname{not} \operatorname{good}=3$, not $\operatorname{good}=2$ and very not $\operatorname{good}=1$, then the total value is calculated. The results of the data validation of the feasibility of material experts, learning design experts, media experts and students use the following formula:

$X=\frac{\text { total score obtained }}{\text { total score of all items }}$

(Sugiyono, 2007)

\section{RESULT AND DISCUSSION}

\subsection{Research result}

\subsubsection{Analysis I; Data Analysis of Initial Product Validation Results}

The results of the assessment by material experts, media experts and learning design experts on each aspect of the overall assessment are determined by the average score in each category. The results of the assessment are then analyzed to determine whether or not it is appropriate to develop the media in sewing technology training. The average percentage of the results of the assessment of material experts, media experts and learning design experts will be described as follows.

1) Analysis of the results of the Material Expert Evaluation

Table 1. Average Percentage of Assessment Results by Material Experts

\begin{tabular}{|c|c|c|c|}
\hline No & Aspect & $\begin{array}{c}\% \\
\text { Average }\end{array}$ & Criteria \\
\hline 1 & $\begin{array}{l}\text { Content } \\
\text { Eligibility }\end{array}$ & 92.5 & Very good \\
\hline 2 & Presentation & 92.0 & Very good \\
\hline 3 & language & 90.0 & Very good \\
\hline 4 & Graphics & 92.5 & Very good \\
\hline & Average & 91.75 & Very good \\
\hline
\end{tabular}

Material experts assess multimedia- based sewing technology learning media based on three aspects, namely aspects of the feasibility of content, presentation, language, and graphics showing the average percentage of each assessment $92.5 \%$ on the aspect of content feasibility $92.0 \%$ on the presentation aspect, $90.0 \%$ on the linguistic aspect and $92.5 \%$ in the graphic aspect, it is categorized as Very Good as a whole, which means that multimedia-based sewing technology learning media can meet the demands of learning needs.

To assess the overall feasibility of multimedia on the assessment of material expert, namely by the formulas:

$$
\begin{gathered}
X t=\frac{\sum X t}{4 x N} \\
X t=\frac{37+184+54+37}{4 \times(2+10+3+2)} \\
X t=\frac{312}{68}=4,58
\end{gathered}
$$

(Very Eligible Category)

The results of the material expert's assessment stated that the media material used Adobe Flash CS6 with the approach learning by doing sewing technology training courses developed are "very feasible" to be used.

2) Data Analysis of Learning Media Expert Evaluation Result

Table 2. Average Percentage of Assessment Results by Media Experts

\begin{tabular}{|l|l|c|c|}
\hline No. & \multicolumn{1}{|c|}{ Aspect } & $\begin{array}{c}\% \\
\text { Average }\end{array}$ & Criteria \\
\hline 1 & $\begin{array}{l}\text { Guide and } \\
\text { Information }\end{array}$ & 73.3 & Well \\
\hline 2 & $\begin{array}{l}\text { Software } \\
\text { Operation } \\
\text { Systematics }\end{array}$ & 75.0 & Well \\
\hline 3 & $\begin{array}{l}\text { Principles of } \\
\text { Media }\end{array}$ & 73.2 & Well \\
\hline & Average & $\mathbf{7 8 . 8}$ & Well \\
\hline
\end{tabular}

Media experts assess the development of sewing technology learning media using Adobe Flash Cs6 with a learning by doing approach based on three aspects, namely guidance and information, software operations and systematics, aesthetics and media principles, showing the average percentage of each assessment. $73.3 \%$ on aspects of guidance and information, $75.0 \%$ on aspects of software operation, and $73.2 \%$.

On the systematic, aesthetic and principle aspects of the media, it is categorized as Good as a whole, which means that the media using Adobe Flash CS6 with a learning by doing approach to the sewing technology training program developed can meet the demands of learning needs.

For the overall media feasibility assessment on the assessment of media experts, namely by the formula:

$X t=\frac{\sum X t}{2 \times N}$ 
$X t=\frac{22+75+183}{2 x(3+10+25)}$

$X t=\frac{280}{76}=3,68$

(Eligible Category)

The result of the media expert's assessment stated that learning multimedia material developed was "worthy" to be used.

3) Data Analysis of Learning Design Expert Evaluation Results

Table 3. Average Percentage of Assessment Results by Design Experts

\begin{tabular}{|l|l|c|c|}
\hline No. & \multicolumn{1}{|c|}{ Aspect } & $\begin{array}{c}\% \\
\text { Average }\end{array}$ & Criteria \\
\hline 1 & Learning Design & 82.5 & $\begin{array}{l}\text { Very } \\
\text { good }\end{array}$ \\
\hline 2 & $\begin{array}{l}\text { Information } \\
\text { Design }\end{array}$ & 81.0 & $\begin{array}{l}\text { Very } \\
\text { good }\end{array}$ \\
\hline 3 & $\begin{array}{l}\text { Presentation } \\
\text { Design }\end{array}$ & 80.0 & Well \\
\hline & Average & $\mathbf{8 1 . 1 7}$ & $\begin{array}{l}\text { Very } \\
\text { good }\end{array}$ \\
\hline
\end{tabular}

Media experts assess media development using Adobe Flash CS6 with a learning by doing approach to sewing technology training based on three aspects, namely learning design, information design and presentation design, showing the average percentage of each assessment. 97.5\% on the learning design aspect, $81.0 \%$ on the information design aspect, and $80.0 \%$ in the design of media presentations, it is categorized as Very Good as a whole, which means that the learning media developed in this study can meet the demands of learning needs.

To assess the overall media feasibility on the assessment of design experts, namely by the formula:

$$
\begin{aligned}
X t & =\frac{\sum X t}{2 x N} \\
X t & =\frac{33+21+84}{2 x(4+10+3)} \\
X t & =\frac{183}{34}=4,06
\end{aligned}
$$

(Very Eligible Category)

The results of the design expert's assessment stated that the media used Adobe Flash CS6 with the approach learning by doing sewing technology training courses developed are "very feasible" to be used.

\subsubsection{Analysis II; Data Analysis of Phase II Trial Result of Individual Trials}

Table 4. Average Percentage of Assessment Results on Individual Trials

\begin{tabular}{|l|l|c|c|}
\hline No. & Aspect & $\begin{array}{c}\% \\
\text { average }\end{array}$ & Criteria \\
\hline 1 & $\begin{array}{l}\text { Guide and } \\
\text { information }\end{array}$ & 88.33 & Totally Agree \\
\hline 2 & Media material & 88,72 & Totally Agree \\
\hline 3 & Evaluation & 85.33 & Totally Agree \\
\hline 4 & $\begin{array}{l}\text { Media design } \\
\text { and facilities }\end{array}$ & 89.33 & Totally Agree \\
\hline 5 & $\begin{array}{l}\text { Pedagogic } \\
\text { effect }\end{array}$ & 92.00 & Totally Agree \\
\hline & Average & $\mathbf{8 8 . 7 4}$ & Totally Agree \\
\hline
\end{tabular}

Table 4 above shows the average percentage of assessment results on individual trials at SMK $\mathrm{N} 1$ Siantar Class $\mathrm{X}$ on the guidance and information aspects of $88.3 \%$, media material aspects of $88.72 \%$, evaluation aspects of $85.33 \%$, aspects of design and media facilities of 89.33 and aspects of pedagogic effects of $92.0 \%$, each of which is included in the category of Strongly agree. Based on the results of the assessment on technology learning media in individual trials, there are no suggestions for improvement.

\subsubsection{Analysis III; Data Analysis of Phase III Trial Results of Small Group Trials}

\begin{tabular}{|c|c|c|c|}
\hline No & Aspect & $\begin{array}{l}\text { Average } \\
\text { percentag }\end{array}$ & Criteria \\
\hline 1 & $\begin{array}{l}\text { Guide and } \\
\text { information }\end{array}$ & 85.56 & $\begin{array}{l}\text { Totally } \\
\text { Agree }\end{array}$ \\
\hline 2 & $\begin{array}{c}\text { Media } \\
\text { material }\end{array}$ & 89.06 & $\begin{array}{l}\text { Totally } \\
\text { Agree }\end{array}$ \\
\hline 3 & Evaluation & 87.11 & $\begin{array}{l}\text { Totally } \\
\text { Agree }\end{array}$ \\
\hline 4 & $\begin{array}{c}\text { Media } \\
\text { designand } \\
\text { facilities }\end{array}$ & 87.56 & $\begin{array}{l}\text { Totally } \\
\text { Agree }\end{array}$ \\
\hline \multirow[t]{2}{*}{5} & $\begin{array}{c}\text { Pedagogic } \\
\text { effect }\end{array}$ & 86.22 & $\begin{array}{l}\text { Totally } \\
\text { Agree }\end{array}$ \\
\hline & Average & 88,10 & $\begin{array}{c}\text { Totally } \\
\text { Agree }\end{array}$ \\
\hline
\end{tabular}

Table 5. Average Percentage of Assessment Results in Small Group Trials

Table 5 above shows the average percentage of assessment results in small group trials at SMK $\mathrm{N} 1$ Siantar Class $\mathrm{X}$ on aspects of guidance and information by $85.56 \%$, aspects of media material by $89.06 \%$, evaluation aspects by $87.11 \%$, aspects of design and media facilities of 87.56 and aspects of pedagogic effects of $86.22 \%$, each of which is in the category of Strongly 
agree. Based on the results of the assessment on the media using Adobe Flash CS6 with a learning by doing approach to sewing technology training developed in small group trials, there are no suggestions for improvement.

\subsubsection{Analysis IV; Data Analysis of Test Results Phase IV Field Trials}

Table 6. Average Percentage of Assessment Results in Field Trials

\begin{tabular}{|c|c|c|c|}
\hline No. & Aspect & $\begin{array}{l}\text { Average } \\
\text { percentage }\end{array}$ & Criteria \\
\hline 1 & $\begin{array}{l}\text { Guide and } \\
\text { information }\end{array}$ & 86.67 & Totally Agree \\
\hline 2 & $\begin{array}{l}\text { Media } \\
\text { material }\end{array}$ & 87,90 & Totally Agree \\
\hline 3 & Evaluation & 88,40 & Totally Agree \\
\hline 4 & $\begin{array}{l}\text { Media design } \\
\text { and facilities }\end{array}$ & 89.13 & Totally Agree \\
\hline 5 & $\begin{array}{l}\text { Pedagogic } \\
\text { effect }\end{array}$ & 90.27 & Totally Agree \\
\hline & Average & 88.47 & Totally Agree \\
\hline
\end{tabular}

Based on Table 6, the following shows the average percentage of assessment results in field trials on students at SMK N 1 Siantar Class X on aspects of guidance and information of $86.67 \%$, media material aspects of $87.90 \%$, evaluation aspects of $88.40 \%$, aspects of design and media facilities are 89.13 and aspects of pedagogic effects are $90.27 \%$, each of which is in the category of Strongly agree. Based on the results of the assessment on sewing technology learning media in the field trial here were no suggestions for improvement.

Thus, revision IV was not held at the field trial stage, which also means that interactive learning media are ready to be tested for their effectiveness.

The results of the assessment of the sewing technology learning media developed in a field trial on 30 students of SMK N 1 Siantar showed that the product developed was very feasible to use and no suggestions for improvement were submitted in this field trial, so revision IV was not carried out.

\subsection{Product Effectiveness Test Results}

\subsubsection{Learning outcomes of students' sewing technology taught using developed media}

Based on the research that has been done on the learning outcomes of sewing technology on students SMK N 1 Siantar which was taught using the developed media, it was found that the student learning outcomes scores of 30 respondents were spread out in the range of 76-93. The calculation results show that the lowest score is 76 and the highest score is 93 with a mean of 83.10 and a standard deviation of 3.91. A complete description of the learning outcomes of students' sewing technology using the developed media is shown in Table 7 below:

Table 7. Value of Learning Outcomes Learned by Using Adobe Flash CS6 Learning Media

\begin{tabular}{|c|c|c|c|}
\hline No. & Score & Frequency & $\%$ \\
\hline 1 & $76-78$ & 2 & 6.7 \\
\hline 2 & $79-81$ & 8 & 26.7 \\
\hline 3 & $82-84$ & 12 & 40.0 \\
\hline 4 & $85-87$ & 5 & 16.7 \\
\hline 5 & $88-90$ & 2 & 6.7 \\
\hline 6 & $91-93$ & 1 & 3.3 \\
\hline & Total & 30 & 100 \\
\hline
\end{tabular}

Table 7 above, shows data on the results of learning sewing technology for students who are taught usingAdobe Flash CS6 media with a learning by doing approach. Based on the average value, it is known that 12 people or $40.0 \%$ are on the average score of learning outcomes, as many as 8 people or $26.6 \%$ are above the average score of learning outcomes and as many as 10 people or $33.4 \%$ are below the average score of learning outcomes.

\subsubsection{Learning Outcomes of Student Sewing Technology Learned Using Clothing Fragments Learning Media}

Based on the research that has been done on the learning outcomes of sewing technology on students SMKN 3 P. Siantar which was taught using the fashion fragment learning media, it was found that the student learning outcomes scores of 30 respondents were spread out in the range of $72-83$. The calculation results show that the lowest score is 72 and the highest score is 83 , the mean is 77.77 and the standard deviation is 3.17 . A complete description of the learning outcomes of students' sewing technology using clothing fragments as media is shown in Table 8:

Table 8. Frequency of Learning Outcomes Values Learned by Using Clothing Fragment Media

\begin{tabular}{|c|c|c|c|}
\hline No. & Score & Frequency & $\%$ \\
\hline 1 & $72-73$ & 3 & 10.0 \\
\hline 2 & $74-75$ & 4 & 13.3 \\
\hline 3 & $76-77$ & 6 & 20.0 \\
\hline 4 & $78-79$ & 8 & 26.7 \\
\hline 5 & $80-81$ & 5 & 16.7 \\
\hline 6 & $82-83$ & 4 & 13.3 \\
\hline & Total & 30 & 100 \\
\hline
\end{tabular}


Table 8 above, shows the data on students' learning outcomes of sewing technology taught by fragment media. Based on the average value, it is known that 8 people or $26.7 \%$ are on the average score of learning outcomes, as many as 9 people or $30 \%$ are above the average score of learning outcomes and as many as 13 people or $43.3 \%$ are below the average score of learning outcomes. Furthermore, the data is arranged in the form of a histogram as shown in Figure 1 below.

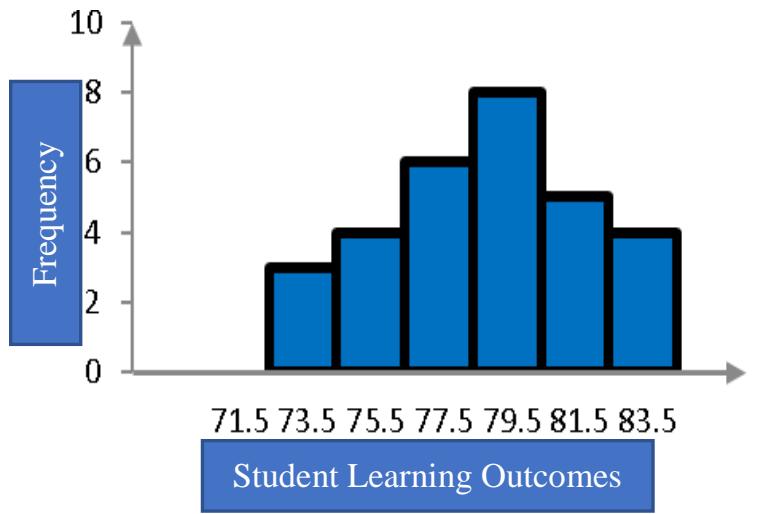

Figure 1. Frequency Histogram of Student Learning Outcomes Using Clothing Fragment Learning Media

\subsection{Testing Requirements Analysis Data Normality Test}

The normality test was made to find the normality of the sample under study. Normality test using the Lilliefors test formula. After calculating, for the experimental class, the value of Lcount $=0.142$, while Ltable at the level of $=0.05$ and $n=30$ is 0.161 . This shows that Lcount $<$ Ltable means that the sample comes from a normally distributed population.

While the normality test of the post- test value for the control class obtained the value of Lcount $=0.071$, while Ltable at the level of $=0.05$ and $n=30$ is 0.161 . This shows that Lcount $<$ Ltable means that the sample comes from a normally distributed population.

Based on the normality test of the two classes above, it can be concluded that the entire population of research data is normally distributed.

\subsubsection{Homogeneity Test}

The homogeneity test calculation data for the posttest value of learning outcomes in the experimental and control groups obtained Fcount $=1.52$ while Ftable was obtained at 1.86 with $=0.05$. So that Fcount $<$ Ftable is $1.52<1.86$, it can be concluded that the data from the two samples for the post-test have the same variation or are homogeneous.

\subsubsection{Hypothesis test}

The hypotheses of this research are as follows: a. With criteria accept Ho if $\mathrm{t} 1-1 / 2 \alpha<\mathrm{t}<\mathrm{t} 1-1 / 2 \alpha$, if the value of $t$ does not meet the equation then the development of Adobe Flash CS6 application learning media with a learning by doing approach ineffective, but if the other $t$ values Ho is rejected, accept $\mathrm{Ha}$ then research and development Adobe Flash CS6 application learning media with a learning by doing approach effectively used.

b. Analysis of the effectiveness can also be concluded that the comparison of the total score obtained with the total score of all items multiplied by one hundred percent, the greater the percentage $X$, the better the level of effectiveness of the media used.

Based on the results of calculations, the data obtained that tcount $>$ ttable or 5,806 > 1,679 or in other words $\mathrm{H} 0$ is rejected and Ha is accepted, it can be concluded that the learning outcomes of sewing technology students who useAdobe Flash CS6 learning media with a learning by doing approach higher than the students who were taught by using the learning media of fashion fragments.

\subsection{Discussion of Research Results}

\subsubsection{Discussion of Research Results of Products Developed}

The series of data validations that have been carried out by experts are then carried out several tests, namely for individuals, small groups and field testing and on students as users. Products developed as media use Adobe Flash CS6 with a learning by doing approach for sewing technology subjects by paying attention to the learning aspects involved. aims to produce media used by students in teaching the material for finishing the edges of clothes in sewing technology training courses. With the use of these media is expected to increase the intensity of the learning process and student competence in sewing technology subjects.

Therefore, the procedure carried out in this study begins with performing: (1) needs analysis, (2) designing a product to be developed as a medium, (3) carrying out product validation by several experts, and (4) making improvements to the perfection of the product. developed as a medium.

The results obtained based on data analysis and testing as well as input from material experts, learning design experts, software engineering experts and students obtained learning media variables have an average value of Very Appropriate, which is assessed to include the feasibility of content, presentation, language, and graphics.

The last step is to make revisions to get the perfection of the product developed. The usefulness of the product 
as a media development using Adobe Flash CS6 with a learning by doing approach for sewing technology training on clothing edge finishing materials, namely: (1) Content can be easier to understand by students because the material is planned to be presented systematically (2) Opportunities for learning students independently without being accompanied by educators (3) The learning process can be more efficient and not boring for students because the products developed as media contain elements of music, animation and video, evaluations are equipped directly with the results of the answers.

\subsubsection{Discussion of Product Feasibility Test Research Results}

The results obtained in studying the material for finishing the edge of clothing in the sewing technology training eye, there is a difference in the value of students who are taught using learning media using Adobe Flash CS6 with a learning by doing approach, the scores are higher than those of students who are taught using clothing fragments learning media.

Exposure to the results of the acquisition of students' scores in the sewing technology training eye means that the product made as a media development is declared effective as a medium to be used to achieve the goal of learning sewing technology for class $\mathrm{X}$ students at SMKN 1 Siantar.

This is also found in research conducted by Istiana (2012) that the media developed using Adobe Flash is easy to understand and able to improve student learning outcomes. Likewise, Dianita Richma Nirmala's research (2015) concludes that the developed media can be interesting. attention and arouse students' enthusiasm and ability to make blazer patterns quickly and correctly. Dina Ampera (2017) which states that based on Adobe Flash CS6 in the subject of making patterns for students is considered eligible by the validator. In testing small groups and large groups, the scores obtained with criteria strongly agree, so interactive multimedia based on Adobe Flash CS6 is feasible to use for teaching student.

Likewise with the research journal Muhamad Awaluddin (2019) which states that the learning-bydoing model applied in his research involves all students' abilities and skills in order to get a logical experience. The application of this model gets a very good and strong response from students so that the learning outcomes obtained are better with an average achievement of $86 \%$ and this can be categorized as very good.

\subsection{Factors of Facilities and Infrastructure}

Mulyasa (2004: 17) says that learning infrastructure and facilities are all sources used to support the teaching and learning process, including buildings, tables and chairs, and the media used. Likewise, Tholib (2000: 97) who says that all learning facilities such as: rooms, books, libraries, laboratories, and others are used to achieve the expected goals of the end of learning.

With the description above, it can be concluded that the availability and use of facilities and infrastructure in learning such as media and other sources of information related to the subject matter taught at face- to-face or even distance learning as is currently happening in the future. The Covid pandemic, which requires distance learning, means that learning media can interact directly with students so as to accelerate the process of understanding and mastering subject matter, and the resulting media has an educational element in it and makes students active and provides a pleasant experience for students.

\subsection{Research Dependencies (Limitations)}

1) Limitations in development research include: this research is limited to media developed using adobe flash CS6 with a learning by doing approach on clothing edge finishing materials.

2) Media testing developed using Adobe Flash CS6 with a learning by doing approach is limited to a sample of 30 students in class X Fashion Design at SMKN 1 Siantar. Extensive testing cannot be carried out, which in the end there is the possibility that several factors can have an impact on the results of this study. Thus, it is better for respondents in the large number of research samples to get an idea from the results of the research conducted.

Limited conditions in the facilities and infrastructure for the manufacture of products that are developed as media in learning such as audio video facilities which in this study greatly affect and hinder researchers from producing products as media development that will be used by teachers in the field of study.

\section{CONCLUSION}

\subsection{Conclusion}

In line with the results of the research in this thesis, namely the development of media using adobe flash CS6 with a learning by doing approach on the material for finishing the edges of clothing for class $\mathrm{X}$ students of fashion style competence at SMKN 1 Siantar, it can be concluded as follows: 1Media using Adobe Flash CS6 with a learning by doing approach with clothing edge finishing material is suitable for use with material expert validation presentations including content feasibility with an average of 92.5 in the very good category, and percentage feasibility with an average of $92.0 \%$ in the very good category, the language aspect with an average of $90.0 \%$ in the very good category, and the graphic aspect with an average of $92.5 \%$ in the very good 
category. For the validation of learning media experts an average of $73.8 \%$ stated good and design expert validation with an average of $81.17 \%$ on very good criteria, media development using Adobe Flash CS6 with a learning by doing approach was declared eligible for eligibility.

Student learning outcomes in sewing technology training courses taught using media using adobe flash CS6 with a learning by doing approach obtained higher results with an average value of 83.10 from the learning outcomes of sewing technology students who were taught using clothing fragments as media with the acquisition of scores an average of 77.77. The learning outcomes of students who are taught using media using Adobe flash CS6 with a learning by doing approach are declared effective in improving student learning outcomes.

\subsection{Implication}

Based on the conclusions and findings in media development research using Adobe Flash CS6 with a learning by doing approach, this media has high implications. The results obtained from this study indicate that students' learning outcomes are higher in value who are taught using media using Adobe Flash CS6 with a learning by doing approach compared to students who learn using clothing fragment media. so that the learning media using Adobe Flash CS6 with a learning by doing approach is more appropriate to use in teaching students.

The implication for teachers in this study is that teachers are obliged to always use all developed infrastructure and technology as a source for the use of media to make it more interesting and choose an approach that is able to provide learning meaning and is adapted to the concepts to be studied and expected.

Each learning media and learning approach has advantages and disadvantages, but the results of this study can be considered for the use of learning media and the selection of approaches in teaching and improving student learning outcomes.

Thus teachers are expected to broaden and add insight and be able to use technology in learning. This can be done by attending training on teaching, seminars and training, especially in the field of technology to improve student learning outcomes and in accordance with the objectives of the SMK.

\subsection{Sugestion}

Based on the conclusions that have been described and the implications of the following research results, some suggestions are proposed as follows:

1. Given that so far the learning process in schools is still using only fragmentary media, it is recommended to use learning media that are more applicable and technology-based and use learning methods or approaches that can relate real-life lessons so as to provide better feedback for students.

2. Principals are advised to support and facilitate teachers in improving student learning outcomes in learning to follow developments in technology, information and communication.

3. The results of this media development research are still possible to be influenced by factors that have not been able to be controlled, so it is necessary to do further research on a larger and wider sample to obtain the perfection of a learning media.

\section{REFERENCES}

[1] Agustin Rinartati and Heni Mustofani (2018), SEWING TECHNOLOGY PT GRAMEDIA

[2] Andi.S (2010).AdobeFlash+XML=Rich Multimedia Application . Yogyakarta: CV Andi Offset.

[3] Anderson and Krathwohl. 2010. A Taxonomy for Learning, Teaching, and Assessing: A Revision of Blo.om's Taxonomy of Educatioanl Objectives (Agung Prihantoro.Translation) New York: Addison Wesley Longman, Inc.

[4] Azhar Arsyad. (2006). Learning Media. Jakarta: PT Raja Grafindo Persada.

[5] Dianitha Richa Nirmala. (2015). Development of Learning Media for Making Blazer Patterns Based on Adobe Flash CS6 for Class XI Clothing Students at SMK Negeri 3 Magelang. Essay. FT UNI.

[6] Dina Indriana. (2011). Variety of Learning Media Tools. Yogyakarta : DIVA Press.

[7] Djemari Mardapi. (2012). Measurement of Educational Assessment and Evaluation. Yogyakarta: Nuha Medika

[8] Dwijanti. (2013). Basic Sewing Technology II. Jakarta: Directorate of Vocational Development.

[9] Emalia Dewi Suryani. (2015). Development of Adobe Flash CS3 Learning Media on Basic Form Competence and Fashion Mode Development for Class XI Clothing Students at SMK Negeri 4 Yogyakarta. Essay. FT UNI.

[10] Endang Mulyatiningsih. (2013). Applied Research Methods in Education. Bandung: Alphabeta

[11] Ernawati, Izweni and Weni Nelmira. (2008). Fashion Design Volume 1. Jakarta: Directorate General of Primary and Secondary Education Management. 
[12] Eveline Siregar and Hartini Nara. (2011). Learning and Learning Theory. Bogor: Ghalia Indonesia.

[13] Hujair AH. Sanaky. (2013). Interactive-innovative Learning Media. Yogyakarta: Kaubaka Dipantara.

[14] Muis Sad Faith. (2004). Participatory Education: Considering the Concept of Fitrah and John Dewey's Progressivism. Yogyakarta: Safiria Insania Press

[15] Nana Sudjana \& Ahmad Rivai. (2010). Teaching Media. Bandung: Sinar Baru Algensindo.

[16] Oemar Hamalik. (1994). Educational Media. Bandung: PT. Image of Aditya Bakti.

[17] Oemar Hamalik. (2008). Teaching and learning process. Jakarta: PT Bumi Aksara.

[18] Porrie Muliawan. (2010). Basics of Sewing Techniques. Jakarta: Libri Publisher

[19] Radias Saleh and Aisyah Jafar. (1991). Basic Techniques of Making Clothing. Jakarta: CV. SIRA SOKA and SONS JAKARTA

[20] Ratna. W. Dahar. (2011). Learning and Learning Theories. Jakarta: Erlangga.

[21] Seels, Barbara B. and Rita C. Richey. 1994. Learning Technology, Definitions and Areas (Instructional Technology: The Definition and Domains of the Filed) Translated by Dra. Dewi S. Prawiradilaga, et al. Jakarta: UNJ

[22] Sugiyono. (2015). Educational Research Methods. Bandung: CV Alfabeta. Sugiyono. (2010). Statistics for Research. Bandung: CV Alfabeta.

[23] S. Arikunto. (2010). Research Procedure A Practical Approach. Jakarta: Rineka Cipta.

[24] Hard. (2013). Competency Education Research Methodology and Practice. Jakarta: PT Bumi Aksara.

[25] Theresia Ari Prabawati. (2008). Adobe Flash CS3 Professional. Yogyakarta: CV Andi Offset.

[26] UNI Team. (2013). Guidelines for Compiling Thesis Final Project. Yogyakarta: UNY.

[27] Trianto. (2014). Integrated Learning Model. Jakarta: Earth Literacy.

[28] Tyas Putri Wardani. (2016). Development of Learning Videos for Sewing Various Parts in Basic Sewing Technology Subjects at SMK N 6 Yogyakarta. Essay. FT UNI.

[29] Warsita, Bambang. 2008. Learning Technology, Foundations and Applications. Jakarta: Rineka Cpta

[30] Widhiastuti. (2007). The Effectiveness of the Implementation of $\mathrm{KBK}$ at the State Vocational
School of Fashion Design Expertise in the City of Yogyakarta Judging from the Achievement of Student Competency Standards. Thesis. PPs-UNY.

[31] Ayu Wardhani. (2015). A History of Adobe's Advantages and Weaknesses. Accessed from http://oret0.blogspot.co.id/2015/02/sejar adobe.html Accessed on November 30, 2016, at 15:14 WIB.

[32] Agustin Rinartati and Heni Mustofani (2018), SEWING TECHNOLOGY PT GRAMEDIA

[33] Andi. (2005). Creating Animated Presentations with Macromedia Flash MX 2004. Yogyakarta:

[34] Andi Sunyoto. (2010). Adobe Flash + XML $=$ RichMultimediaApplication Yogyakarta: CV Andi Offset.

[35] Anderson, Lorin W. \& Krathwohl, David R. 2010. A Fundamental Framework for Learning, Teaching, and Assessment. Yogyakarta:Student Library.

[36] Arshad, Azhar. (2013). Learning Media. Jakarta: Rajawali Press

[37] Asnawir and Bashiruddin. (2002). LEARNING MEDIA. Jakarta: Ciputat Press.

[38] Baharuddin, Wahyuni. 2010. Learning and Learning Theory. Yogyakarta: Ar-Ruzz Media.

[39] Budiarjo, Lily. 2007. Learning Skills. Yogyakarta: Andi . Publisher

[40] Darmadi. 2017. Development of Learning Method Models in Student Learning Dynamics. Yogyakarta: CV Budi Utama.

[41] Daryanto. (2011). Learning Media. Bandung: One Nusa.

[42] Dwijanti. (2013). Basic Sewing Technology II. Jakarta: Directorate of Vocational Development.

[43] Endang Mulyatiningsih. (2013). Applied Research Methods in Education. Bandung: Alphabeta

[44] Ernawati, Izweni and Weni Nelmira. (2008). Fashion Design Volume 1. Jakarta: Directorate General of Primary and Secondary Education Management.

[45] Gulö, W. 2002. Teaching and Learning Strategies. Jakarta: Grasindo.

[46] Halida, Farihah, Flora and Rasita (2018), Fashion Technology. Medan Madenatera Qualifie Dpunlisher

[47] Hujair AH. Sanaky. (2013). Interactive-innovative Learning Media. Yogyakarta: Kaubaka Dipantara. 
[48] Hurry. (2018). Student Center Learning Method Application in Nursing Education. Jakarta :Prenadamedia Group

[49] Jibril, A. (2011). Adobe Flash Flash Skills. Yogyakarta: Computer World.

[50] Kopecky, K. (2009). Adobe Flash Platform for Creator of Online Multimedia Educational Content. Journal of Technology and Information Education, Volume 1, Issue 3, ISSN 1803-537 X.

[51] Minister of National Education. 2003. Law of the Republic of Indonesia Number 20 of 2003 concerning the National Education System. Bandung : CV. Umbara image.

[52] Macdoms. (2012). Full Peel Adobe Flash Professional CS6. Yogyakarta:

[53] Mulyasa, E. (2013). Development and Implementation of Curriculum 2013. Bandung: PT Pemuda Rosdakarya.

[54] Nana Sudjana \& Ahmad Rivai. (2010). Teaching Media. Bandung: Sinar Baru Algensindo.

[55] Nata, A. 2009. Islamic perspective on learning strategies. Jakarta : Kencana.

[56] Nensi, et al. 2017. Application of Problem Based Learning (PBL) Learning Model to Improve Learning Outcomes of SM Students on Business and Energy Materials. Al-BiRuNi Scientific Journal of Physics Education. ISSN: 2503-023X

[57] Oemar Hamalik. (1994). Educational Media. Bandung: PT. Image of Aditya Bakti.

[58] Porrie Muliawan. (2010). Basics of Sewing Techniques. Jakarta: Libri Publisher

[59] Prof. Dr. H. Aminuddin Rasyad, et al, 1997, Main Material of Teaching Media, Directorate General of Islamic Institutional Development and UT

[60] Pranowo, G. (2011). Interactive Animation Creation with Action Script 3.0 in Flash CS5. Yogyakarta : Andi Offset.

[61] Radias Saleh and Aisyah Jafar. (1991). Basic Techniques of Making Clothing. Jakarta: CV. SIRA SOKA and SONS Jakarta

[62] Ratna Wilis Dahar. (2011). Learning and Learning Theories. Jakarta: Erlangga.

[63] Riyana, Cepi. and Susanna, Rudi. 2009. LEARNING MEDIA: Nature, Development, Utilization and Assessment. Bandung: CV WACANA PRIMA.

[64] Rusyna, Adun. 2014. Thinking Skills. Yogyakarta. Wave Publisher.
[65] Sadjiman, Arief S. (et al). 2005. EDUCATIONAL MEDIA:

[66] Definition, Development and Utilization. Jakarta: PT RajaGrafindo Persada

[67] Sugiyono. (2015). Educational Research Methods. Bandung: CV Alfabeta.

[68] Sugiyono. (2010). Statistics for Research. Bandung: CV Alfabeta.

[69] Suharsimi Arikunto. (2010). Research Procedure A Practical Approach. Jakarta: Rineka Cipta.

[70] Surya, Mohammad. 1992. Educational Psychology 5th Edition (Revised). Bandung: Department of PPB FIP UPI.

[71] Sutopo, AH (2003). Interactive Multimedia with Flash. Yogyakarta: Graha Ilmu 